\title{
Hazardous Waste Generation and Composition from Electric Train Activities
}

\author{
Nabila Ardiana a , I Wayan Koko Suryawan ${ }^{\text {a,b }}$, Betanti Ridhosari ${ }^{\text {a }}$, Mega Mutiara Sari ${ }^{\text {a }}$ \\ ${ }^{a}$ Department of Environmental Engineering, Faculty of Infrastructure Planning, Universitas Pertamina, Komplek Universitas Pertamina, DKI Jakarta, \\ Jakarta Selatan, Indonesia \\ b College of Environmental Studies, National Dong Hwa University, Hualien, Taiwan \\ * corresponding author: i.suryawan@universitaspertamina.ac.id \\ DOI : 10.20885/ijca.vol5.iss1 .art7
}

\section{ARTIKEL INFO}

Received : 10 February 2022

Revised : 18 February 2022

Published : 01 March 2022

Keywords : hazardous waste, electric

waste, waste composition

\begin{abstract}
Transportation is one of the human needs in a big city like Jakarta. Currently, the implementation of public transportation is being scaled up to reduce vehicle emissions, especially those fueled by oil. One public transportation activity is electric trains that produce hazardous solid waste. This study aims to identify the generation and composition of hazardous waste from electric train transportation activities in Jakarta. This study uses quarterly secondary data from July 2019 to March 2020. The composition of hazardous waste is calculated based on the $\mathrm{w} / \mathrm{w}$ weight ratio, then looks at the effect of time and phase of each time hazardous waste generation from electric train activities. The composition of the largest hazardous waste is contaminated packaging, scrapcontaminated, and contaminated waste is $28.14 \%$; $23.34 \%$; and $10.72 \%$, respectively. The lowest hazardous waste generated is used lamps at $0.10 \%$. Hazardous waste arises from activities that contaminate to produce hazardous or toxic properties. Based on the phase, solid hazardous waste is $96 \%$, and liquid is $4 \%$. The analysis of the variance test showed no significant difference in terms of time (sig. 0.679) and phase (sig. 0.534). Therefore, the data used show no difference in hazardous waste generated by time or phase.
\end{abstract}

\section{INTRODUCTION}

Modern, comfortable, and safe public transportation is everyone's goal. However, many transportations are still uncomfortable and safe, especially in Indonesia [1]. Many transportations are still less convenient to use because many prefer to use private vehicles. The number of private vehicles on the streets makes the roads congested in many places. To reduce congestion that occurs, public transportation is one solution [2]. Convenient and safe public transportation is an option that many people consider. Another option that is also considered as fast is public transportation, which doesn't waste a lot of time

One of the community facilities and infrastructure in public transportation is the electric train [3]. The high-speed train that is being developed uses electric power. The form of management to reduce environmental pollution is the management of Hazardous and Toxic Materials waste. Hazardous waste from train operations in Indonesia uses used oil, waste oil, residual oil and fuel, contaminated metal, and others [4]. 
According to the annual report on the operation of electric trains in Vietnam, hazardous waste generated from electric train activities in Vietnam produces residual oil, ink, used lamps, batteries, fuel residue, residual oil, and sludge [5]. Almost the same as the electric train in Columbia, hazardous waste generated from operational activities in the form of paint, asbestos, Printed Circuit Board (PCB), residual oil, residual oil, and other electronic waste [6].

One of the environmental impacts of hazardous waste is soil and water contamination, contaminated with hazardous waste and categorized as an ecological disaster [7]. Ecological disasters will later impact human health, which accumulates into the food chain resulting in poisoning, carcinogenicity, and death [8]. Electric rail trains are electric rail trains that are operated across Jakarta. The use of electric rail is a new thing to operate in Indonesia. Therefore, it is necessary to know environmental management including hazardous waste in this sector. This study aims to identify the generation and composition of hazardous waste from electric train transportation activities in Jakarta

\section{METHOD}

Secondary data is obtained from the amount of hazardous waste generated, inventory records every day, and based on the hazardous waste manifest used in operations due to the amount of hazardous waste in actual conditions. This data is obtained from the Management's Material Safety Data Sheet (MSDS).

The following secondary data is the time of collecting hazardous waste from each station to the Jakarta electric train depot as supporting data for collecting hazardous waste. This study uses quarterly secondary data from July 2019 to March 2020. The data that has been collected is then processed and analyzed based on their respective functions. The secondary data used is an inventory of hazardous waste data per day. The data processing aims to determine the average hazardous waste from the amount of hazardous waste generated per day according to the characteristics of each hazardous waste generated from electric train operational activities (equation 1):

$$
\begin{aligned}
& \bar{x}=\sum \frac{x_{i}}{n} \\
& \bar{x}=\text { average hazardous waste (mass or volume) } \\
& \mathrm{n}=\text { total sample } \\
& \mathrm{x}_{\mathrm{i}}=\mathrm{i} \text {-th observation value }
\end{aligned}
$$

The average result will determine the hazardous waste generated according to the characteristics. This average can be used to reference hazardous waste stored in temporary shelter. Hazardous waste is stored for three months until a third party transports the hazardous waste.

Hazardous waste composition data in this study were analyzed using the ANOVA test. The ANOVA test compares the population averages to find out the significant differences between two or more data groups. The data group used in this study is the time and phase of hazardous waste to hazardous waste generation at the study site. ANOVA analysis using SPSS.

\section{RESULT AND DISCUSSION}

Figure 1 shows the amount of hazardous waste generated at an electric train facility in Jakarta. Hazardous waste generated must be appropriately managed and correctly to not harm the environment. Hazardous waste management involves storing, collecting, utilizing, transporting, and handling hazardous waste [9], [10]. This management is expected to minimize the generation of hazardous waste generated by reducing generation from sources by minimizing the use of raw materials that have initially been dangerous to non-hazardous. In addition, using eco-friendly technology, selecting and implementing reducing environmental scenarios for reducing negative impact more efficient production processes [11]. 


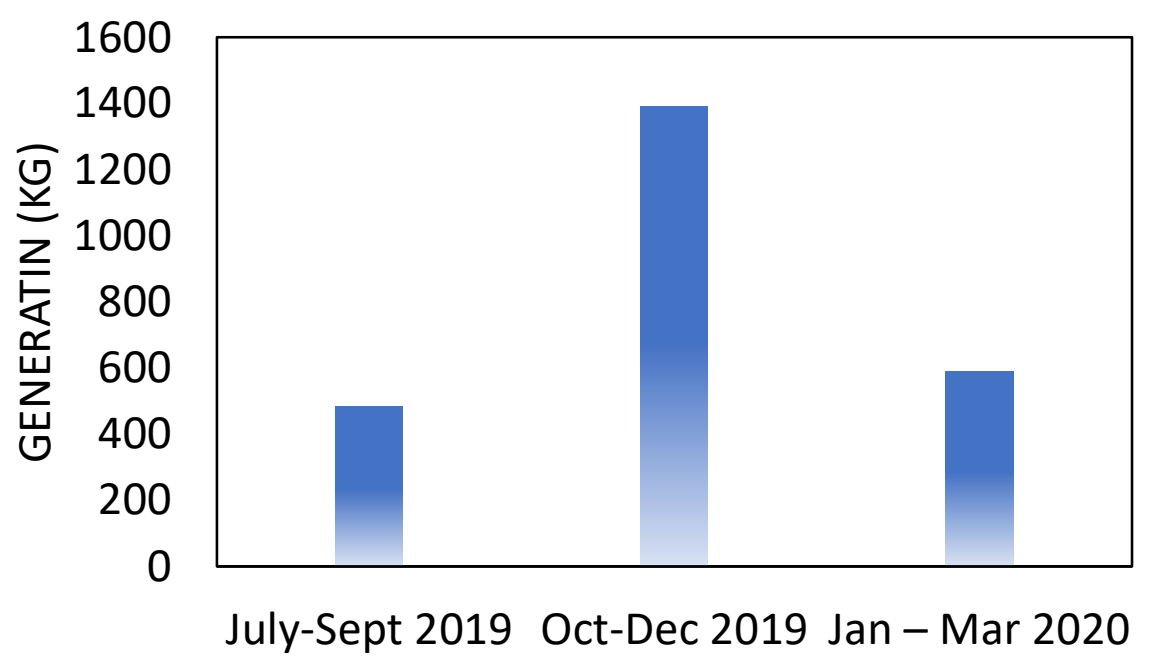

Figure 1. Hazardous Waste Generation Quarterly in Electric Train Facilities

Based on Table 1, the Jakarta electric train hazardous waste composition has various amounts. Hazardous waste that is not necessarily generated per month is grease trap waste, gram lathe residue, used lamps, ferrous metal, used batteries, used rags, contaminated packaging, used batteries, and AC filters. Hazardous waste with the largest percentage is contaminated packaging with $28 \%$, followed by contaminated scrap at $23 \%$. The number of contaminated packaging is greater because it is produced every month. In contrast to contaminated scrap produced only six months earlier, January - March 2020 did not produce contaminated scrap. The smallest percentage produced is used lamps with a value of $0.10 \%$, activities that produce hazardous waste in the form of lamps are only in January - March 2020 with a total of $2.4 \mathrm{~kg}$.

TABLE I. Categories and Composition of Hazardous Waste Electric Train Facilities

\begin{tabular}{|c|c|c|c|c|c|c|}
\hline Category & Code & $\begin{array}{l}\text { July-Sept } \\
2019 \\
\text { Total (kg) }\end{array}$ & $\begin{array}{c}\text { Oct-Dec } \\
2019 \\
\text { Total } \\
(\mathrm{kg}) \\
\end{array}$ & $\begin{array}{c}\text { Jan - } \\
\text { Mar } \\
2020 \\
\text { Total } \\
(\mathrm{kg}) \\
\end{array}$ & $\begin{array}{l}\text { Total } \\
(\mathrm{kg})\end{array}$ & Type \\
\hline Grease trap waste & $\begin{array}{c}\text { A355- } \\
1\end{array}$ & 0 & 0 & 29.8 & 29.8 & Liquid \\
\hline Used battery & $\begin{array}{c}\mathrm{A} 345- \\
2\end{array}$ & 0 & 0 & 120.4 & 120.4 & Solid \\
\hline Used oil & $\mathrm{B} 107 \mathrm{~d}$ & 0 & 0 & 2.4 & 2.4 & Solid \\
\hline The remaining grams of lathe & $\begin{array}{c}\text { A345- } \\
2\end{array}$ & 0 & 0 & 90 & 90 & Solid \\
\hline Used lamp & $\mathrm{A} 102 \mathrm{~d}$ & 0 & 51 & 8 & 59 & Liquid \\
\hline Metal iron & B110d & 5.8 & 76.8 & 11.2 & 93.8 & Solid \\
\hline Second hand & B104d & 68 & 483 & 142.3 & 693.3 & Solid \\
\hline Contaminated packaging & B109d & 0 & 61 & 86 & 147 & Solid \\
\hline AC filters & $\mathrm{B} 107 \mathrm{~d}$ & 0 & 37 & 99 & 136 & Solid \\
\hline Used battery & B110d & 3.2 & 2.9 & 0 & 6.1 & Liquid \\
\hline Scrap contaminated & A108d & 407 & 168 & 0 & 575 & Solid \\
\hline Metal drums & $\mathrm{B} 105 \mathrm{~d}$ & 0 & 188.6 & 0 & 188.6 & Solid \\
\hline Medical waste & $\begin{array}{c}\text { A } 377- \\
1\end{array}$ & 0 & 58.3 & 0 & 58.3 & Solid \\
\hline Contaminated waste & $\mathrm{A} 108 \mathrm{~d}$ & 0 & 264.2 & 0 & 264.2 & Solid \\
\hline
\end{tabular}


Contaminated hazardous waste is hazardous waste that is produced in the largest number and according to PP no. 101 of 2014 is given the code B104d, namely hazardous used packaging with category 2. Hazardous waste contaminated packaging is usually used for garage or workshop activities and used drugs and chemicals, and this hazardous waste is commonly used for industrial factories [12]. Then for hazardous waste, contaminated scrap, namely metal that has been contaminated with dangerously contains toxic properties and according to PP no. 101 of 2014 waste code A108d with category 1 . Hazardous waste like contaminated scrap or metal is commonly found in industrial activities [13].

Other hazardous wastes such as used oil, batteries, and rags are hazardous waste originating from waste train facilities [4]. Hazardous waste of used oil used batteries, and used rags need to be managed by hazardous waste by collecting and storing hazardous waste. Grease trap hazardous waste is dangerous liquid waste originating from industrial wastewater treatment by gradually separating oil by gravity [14], [15]. Infectious waste is the result of health activities and infects the body [16]-[18]. Therefore, hazardous waste is categorized as infectious with a total of $58.3 \mathrm{~kg}$ with a composition of 2\% in October - December 2019 (Figure 2).

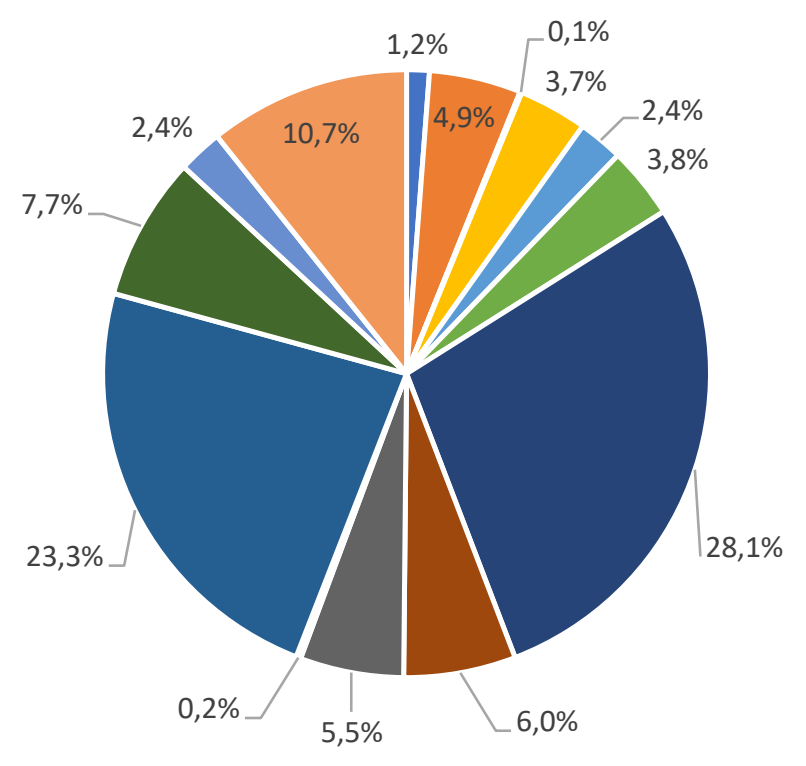

\author{
- Grease trap waste \\ - The remaining grams of lathe \\ - Used lamp \\ - Metal iron \\ - Used battery \\ - Second hand \\ - Contaminated packaging \\ - AC filters \\ - Used battery \\ - Used oil \\ - Scrap contaminated
}

Figure 2. Hazardous Waste Composition in Electric Train Facilities

Figure 3 shows the composition of hazardous waste by phase. Solid waste comes from activities, and business results in solid form. Solid waste is usually found in domestic waste in household activities, trade, offices, livestock, agriculture [19]. The form of liquid waste can be in the form of suspended domestic wastewater or dissolved in water. Meanwhile, hazardous waste is waste originating from business activities and results. It is hazardous or toxic because the nature and amount of the waste will directly or indirectly pollute the environment and/or human health. 


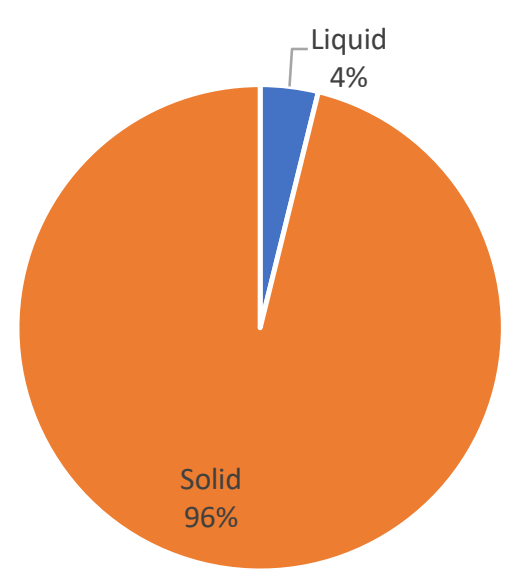

Figure 3. Hazardous Waste Composition Base on Phase in Electric Train Facilities

Table 2 shows the results of the variance test from this study. It can be seen that the phase variable (sig. 0.534) and time (sig. 0.679) of hazardous waste generation are no different from July 2019 to March 2020. Meanwhile, the type of waste generated is also no different.

TABLE II. ANOVA analysis results

\begin{tabular}{|c|c|c|c|c|c|c|}
\hline Source & $\begin{array}{c}\text { Dependent } \\
\text { Variable }\end{array}$ & $\begin{array}{c}\text { Type III Sum of } \\
\text { Squares }\end{array}$ & df & $\begin{array}{c}\text { Mean } \\
\text { Square } \\
\end{array}$ & $\mathbf{F}$ & Sig. \\
\hline \multirow{2}{*}{ Corrected Model } & Phase & $3.914^{\mathrm{a}}$ & 23 & 0.17 & 0.97 & 0.534 \\
\hline & Time & $14.316^{\mathrm{b}}$ & 23 & 0.622 & 0.819 & 0.679 \\
\hline \multirow[t]{2}{*}{ Intercept } & Phase & 79.424 & 1 & 79.424 & 452.718 & 0 \\
\hline & Time & 120.645 & 1 & 120.645 & 158.694 & 0 \\
\hline \multirow[t]{2}{*}{ Waste Generation } & Phase & 3.914 & 23 & 0.17 & 0.97 & 0.534 \\
\hline & Time & 14.316 & 23 & 0.622 & 0.819 & 0.679 \\
\hline \multirow[t]{2}{*}{ Error } & Phase & 3.158 & 18 & 0.175 & & \\
\hline & Time & 13.684 & 18 & 0.76 & & \\
\hline \multirow[t]{2}{*}{ Total } & Phase & 141 & 42 & & & \\
\hline & Time & 196 & 42 & & & \\
\hline \multirow[t]{2}{*}{ Corrected Total } & Phase & 7.071 & 41 & & & \\
\hline & Time & 28 & 41 & & & \\
\hline \multicolumn{7}{|c|}{${ }^{\mathrm{a}} \mathrm{R}$ Squared $=.553$ (Adjusted R Squared $=-.017$ ) } \\
\hline
\end{tabular}

\section{CONCLUSION}

Hazardous waste generated on the Jakarta electric train from July 2019 to March 2020 in the form of grease trap waste, gram lathe, used lamps, metal iron, used batteries, used rags, chemically contaminated packaging, AC filters, and used batteries. Hazardous waste generation with the highest composition is contaminated packaging at $28 \%$, and the smallest is used lamps at $0.10 \%$. Further research is needed on time series management to find out more detailed impacts of electric trains. This management can help prevent the adverse effects of hazardous waste reactions more broadly.

\section{References}

[1] Prakarsa, "Moving People in Jakarta," Prakarsa, 2014. 
[2] R. Merkert, J. Bushell, and M. J. Beck, "Collaboration as a service (CaaS) to fully integrate public transportation - Lessons from long distance travel to reimagine mobility as a service," Transp. Res. Part A Policy Pract., vol. 131, pp. 267-282, 2020.

[3] P. Ricardianto, E. Purnomo, E. Widodo, and M. Hidayat, "ANALYSIS OF FACTORS CAUSING JABODETABEK COMMUTER TRAIN DELAY," J. Econ. Manag. Entrep. Bus., vol. 1, no. 2 SEArticles, pp. 170-178, Nov. 2021.

[4] A. Sillahudin, Evaluasi dan Inventarisasi Pengelolaan Limbah B3 di UPT Balai Yasa PT. KAI. Yogyakarta: Universitas Islam Indonesia., 2018.

[5] CDM, Semi-Annual Report Juli 2015 VIE: Ho Chi Minh City Mass Rapid Transit Line 2 CP1: Initial Depot Works. Vietnam: Initial Tham Luong Depot. Ho Chi Minh: Initial Tham Luong Depot, 2015.

[6] T. Abdallah, Environmental Impacts, Sustainable Mass Transit, 45-59. Netherlands, 2017.

[7] B. V. Babu and V. Ramakhrishna, Hazardous Waste Management in India. India: Rajasthan., 2015.

[8] S. Jiwan and K. Ajay, "Effects of Heavy Metals on Soil, Plants, Human Health and Aquatic Life," Int. J. Res. Chem. Environ., vol. 1, no. January, pp. 15-21, 2011, [Online]. Available: www.ijrce.org.

[9] S. D. Prameswari, M. A. Nurhadi, I. Rizaldi, M. Octaviani, I. W. K. Suryawan, and B. Ridhosari, "Design of Hazardous Waste Station in Xyz Radioactive Industry," J. Envirotek, vol. 12, no. 1, pp. 80-86, 2020.

[10] A. Wibisono et al., "Design of Hazardous Waste Station in XYZ Port, Jakarta City," Civ. Environ. Sci., vol. 003, no. 02, pp. 110-118, 2020.

[11] I. W. K. Suryawan, A. Rahman, J. Lim, and Q. Helmy, "Environmental impact of municipal wastewater management based on analysis of life cycle assessment in Denpasar City," Desalin. Water Treat., vol. 244, pp. 55-62, 2021.

[12] T. T. Nguyen et al., "Current Status of the Management of Plant Protection Product Containers in Cho Moi District, An Giang Province, Vietnam," Nakhara J. Environ. Des. Plan., vol. 20, pp. 1-14, 2021.

[13] F. Leilan, T. Revina, I. Dimassetya, and A. Rahmanissa, "Scrap Metal Reduction as the Effect of Combustor Upgrade in GTG 1.3 PLTGU Muara Karang," IOP Conf. Ser. Mater. Sci. Eng., vol. 1096, no. 1, p. 12091, 2021.

[14] P. Sanghamitra, D. Mazumder, and S. Mukherjee, "Treatment of wastewater containing oil and grease by biological method- a review," J. Environ. Sci. Heal. Part A, vol. 56, no. 4, pp. 394-412, Mar. 2021.

[15] N. L. Pangestu, N. L. Zahra, and A. Sarwono, "Produced Water Treatment Planning Using Corrugated Plate Interceptor and Ultra Filtration for Water Recycling," J. Serambi Eng., vol. VI, no. 4, pp. 2286-2293, 2021.

[16] Septiariva, A. Sarwono, I. W. K. Suryawan, and B. S. Ramadan, "Municipal Infectious Waste during COVID-19 Pandemic: Trends, Impacts, and Management," Int. J. Public Heal. Sci., vol. 11, no. 2, 2022.

[17] I. Sholikhah, D. Sekarsari, A. D. Nastiti, N. Ulhasanah, and I. W. K. Suryawan, "Analisa Pengolahan Limbah Alat Pelindung Diri Covid-19 sebagai Substitusi dalam Pembuatan Sandwich Panel," JTERA (Jurnal Teknol. Rekayasa), vol. 6, no. 2, p. 201, 2021.

[18] I. Rahmalia, N. Y. Oktiviani, F. S. Kahalnashiri, N. Ulhasanah, and I. W. K. Suryawan, "Pengelolaan Limbah Alat Pelindung Diri (APD) di Daerah Jakarta Barat Berbasis Smart Infectious Waste Bank (SIWAB)," J. Ilmu Lingkung., vol. 20, no. 1, pp. 91-101, 2022.

[19] H. I. Abdel-Shafy and M. S. M. Mansour, "Solid waste issue: Sources, composition, disposal, recycling, and valorization,” Egypt. J. Pet., vol. 27, no. 4, pp. 1275-1290, 2018.

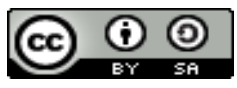

Jurnal IJCA is licensed under aÂ Creative Commons Attribution ShareAlike 4.0 